\title{
Enzyme Replacement with Recombinant $\beta$-Glucuronidase in the Newborn Mucopolysaccharidosis Type VII Mouse
}

\author{
CAROLE VOGLER, MARK SANDS, ANN HIGGINS, BETH LEVY, JEFFERY GRUBB, \\ EDWARD H. BIRKENMEIER, AND WILLIAM S. SLY \\ Department of Pathology [C.V., B.L.] and The Edward A. Doisy Department of Biochemistry and Molecular \\ Biology [J.G., W.S.S.], the St. Louis University School of Medicine, St. Louis, Missouri 63104 and The Jackson \\ Laboratory [M.S., A.H., E.H.B.], Bar Harbor, Maine 04609
}

\begin{abstract}
Glucuronidase injected i.v. into newborn mucopolysaccharidosis VII mice was cleared from the circulation in less than $1 \mathrm{~h}$ and taken up by tissues in a distribution corresponding to the location of the mannose 6-phosphate receptor. One h after a $3.5-\mathrm{mg} / \mathrm{kg} \beta$-glucuronidase injection, $\beta$-glucuronidase levels were equal to or greater than normal in every organ examined with the exception of the brain, where $31 \%$ normal activity was present. Enzyme was detectable histochemically in the major sites of pathology for mucopolysaccharidosis VII including bone, brain, heart, and fixed tissue macrophages. The half-life of recombinant $\beta$-glucuronidase activity in various organs of injected mucopolysaccharidosis VII mice was 1.5 to $4.5 \mathrm{~d}$. These studies show that recombinant $\beta$ glucuronidase administered to newborn mice reaches the sites of clinically important storage in murine mucopolysaccharidosis VII. (Pediatr Res 34: 837-840, 1993)
\end{abstract}

\section{Abbreviations}

MPS, mucopolysaccharidosis

$\beta$-gluc, $\beta$-glucuronidase

BMT, bone marrow transplantation

Man 6-P, mannose 6-phosphate

The mucopolysaccharidoses are inherited disorders, each caused by a deficiency of one of the lysosomal enzymes necessary for the degradation of glycosaminoglycans. Affected patients have glycosaminoglycan accumulation in lysosomes and progressive organ dysfunction. A murine model of MPS type VII that lacks $\beta$-gluc (EC 3.2.1.31) shares many clinical, biochemical, and pathologic features with human MPS VII (Sly syndrome) (1, 2 ) and allows controlled therapeutic studies of genetically identical animals.

Infusion of deficient lysosomal enzyme has been proposed as a therapy for lysosomal storage diseases (3). However, sufficient quantities of lysosomal enzymes with the recognition markers needed for receptor-mediated endocytosis have not been available, except for glucocerebrosidase in Gaucher disease. The availability of large quantities of phosphorylated recombinant $\beta$ -

Received for rapid publication July 30, 1993; accepted August 26, 1993

Correspondence: Carole Vogler, Department of Pathology, Cardinal Glennon Children's Hospital, 1465 S. Grand Blvd., St. Louis, MO 63104.

Supported by NIH Grant DK41082 to E.H.B and C.V., DK40163 and GM 34182 to W.S.S. and NRSA DK07449 and DK08546 to M.S. gluc (4) made experimental enzyme replacement therapy for murine MPS VII feasible. Newborn MPS VII mice have only small amounts of lysosomal storage (2) and enzyme therapy instituted early in life might prevent further accumulation of storage and arrest disease progression. We present evidence that i.v. administered $\beta$-gluc is taken up by many tissues in the MPS VII mouse and its cellular distribution is similar to that reported for the Man 6-P/IGF-II receptor responsible for receptormediated endocytosis and targeting of lysosomal enzymes to lysosomes $(5,6)$.

\section{MATERIALS AND METHODS}

Twenty-eight thousand units of recombinant $\beta$-gluc (approximately $3.5 \mathrm{mg} / \mathrm{kg}$ ) prepared as previously described (4) and dissolved in $100 \mu \mathrm{L}$ of buffer containing $10 \mathrm{mM}$ Tris (pH 7.5), $150 \mathrm{mM} \mathrm{NaCl}$, and $1 \mathrm{mM} \beta$-glycerol phosphate were injected into the superficial temporal vein of three 1-d-old MPS VII pups. Controls included two homozygous normal and two MPS VII 1d-old pups injected with diluent buffer. All experiments were performed with the highest standards of humane animal care. The Jackson Laboratory is fully accredited by the American Association for Accreditation of Laboratory Animal Care.

Mice were killed $1 \mathrm{~h}$ after the injection. For histochemical study, tissues were immersed in $0.25 \%$ sucrose as a cryopreservative or OCT (Miles, Elkhart, IN) and frozen in liquid nitrogencooled isopentane. Ten- $\mu \mathrm{m}$-thick tissue sections were stained for $\beta$-gluc activity using a histochemical method (7). In two enzymeinjected MPS VII pups and a normal and an MPS VII control, sagittal sections of the whole animal were studied.

$\beta$-gluc activity was assayed (8) in multiple tissues from an enzyme-injected MPS VII pup and compared with the enzyme levels in age-matched untreated MPS VII and normal pups as previously described (1). To determine $\beta$-gluc half-life in MPS VII pups during the 1st wk of life, six mice were injected with $28000 \mathrm{U}$ of $\beta$-gluc at $1 \mathrm{~d}$ of age and one mouse was killed at 24 , $48,72,120$, and $168 \mathrm{~h}$ postinjection. Homogenates of liver, kidney, spleen, lung, heart, brain, and residual carcasses were assayed for $\beta$-gluc activity and protein concentration (9). Log sp act versus time after injection was plotted to calculate enzyme half-life. $r$ values were determined for each of the curves by the least squares method.

\section{RESULTS}

In the MPS VII control pup receiving buffer alone, $\beta$-gluc activity was not identified histochemically or biochemically in any tissue (Fig. $1 A$ ). In contrast, $1 \mathrm{~h}$ after enzyme injection, MPS 
VOGLER $E T A L$.
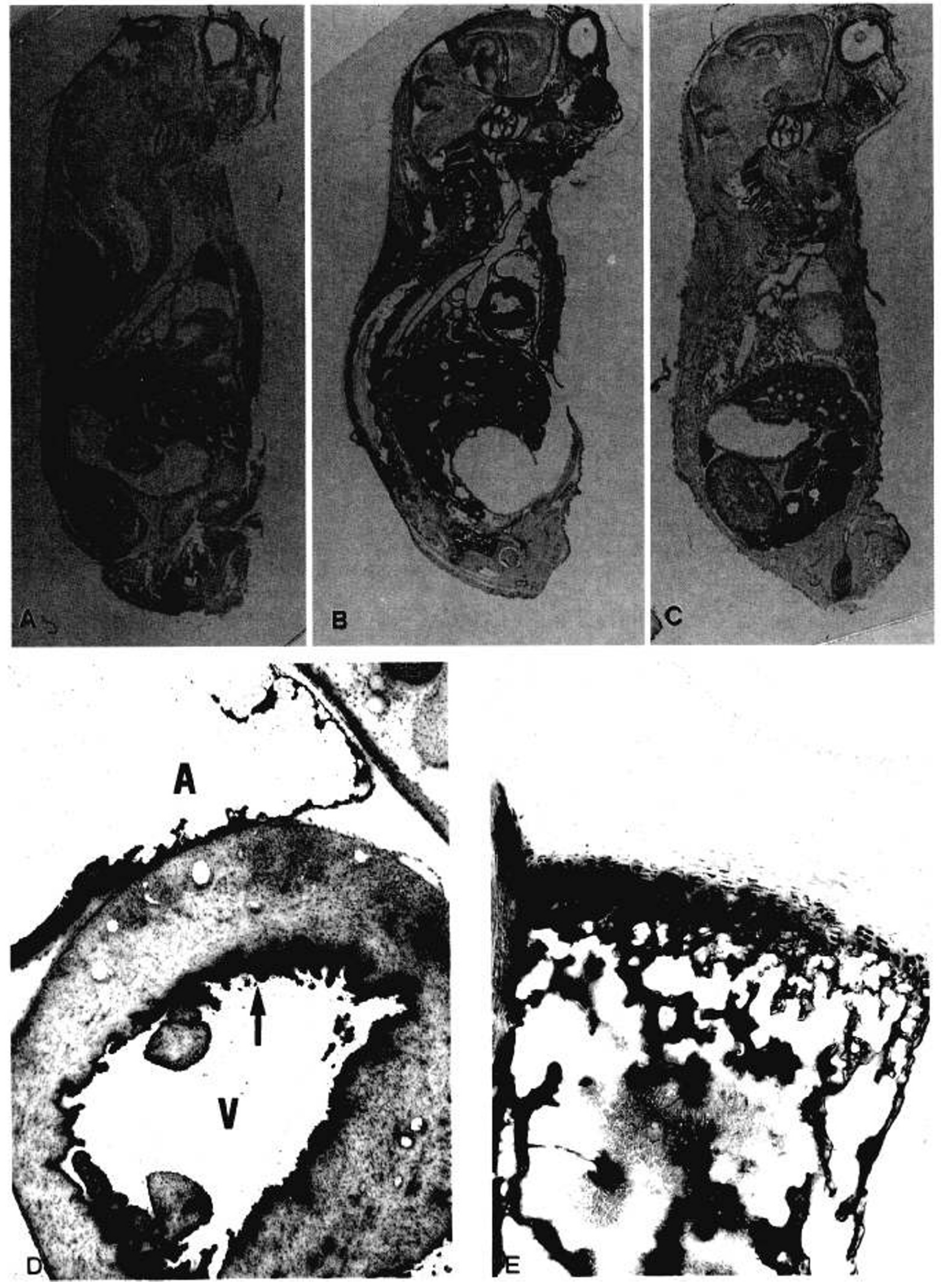

Fig. $1 D$

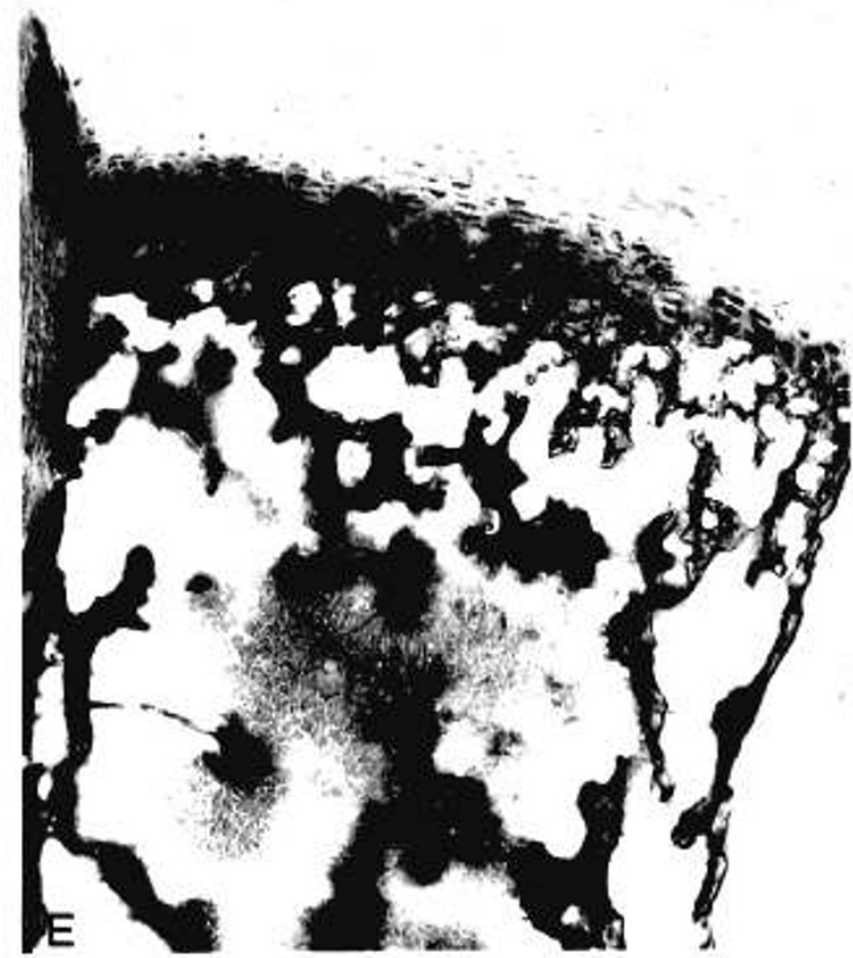

Fig. $1 E$ 
VII pups had $\beta$-gluc activity in multiple sites (Fig. $1 B$, Tables 1 and 2 ). Although the intensity of staining was less overall in the normal control pup, the distribution of $\beta$-gluc activity was similar in many sites to that in the MPS VII pup after enzyme injection (Fig. 1C, Table 2).

The fixed tissue macrophage system in MPS VII pups readily took up injected $\beta$-gluc. Other sites, including the endocardium (Fig. $1 D$ ) and bone (Fig. $1 E$ ), also showed intense enzyme activity after injection. In the stomach and small intestine, the lamina propria contained abundant, diffuse enzyme activity, and in the small intestine, villus epithelial cells had activity in circumscribed supranuclear zones. However, crypt epithelium contained no activity. In the CNS of injected MPS VII pups, $\beta$-gluc activity was present in vessels, meninges (Fig. $1 F$ ), and the connective tissue core of the choroid plexus. Although we could not identify enzyme activity in the CNS neurons, ganglia neurons in the peripheral nervous system had a small amount of $\beta$-gluc activity.

One $\mathrm{h}$ after the single injection, approximately $70 \%$ of the injected enzyme was recovered in homogenates of organs and carcasses of MPS VII pups and less than $1 \%$ remained in the plasma. With the exception of the CNS, which contained $31 \%$ normal activity, normal or greater than normal levels of $\beta$-gluc activity were present in all organs examined (Table 2 ). The halflife of the injected recombinant $\beta$-gluc during the 1 st wk of life was different in each tissue and was longest in the brain (Table 2).

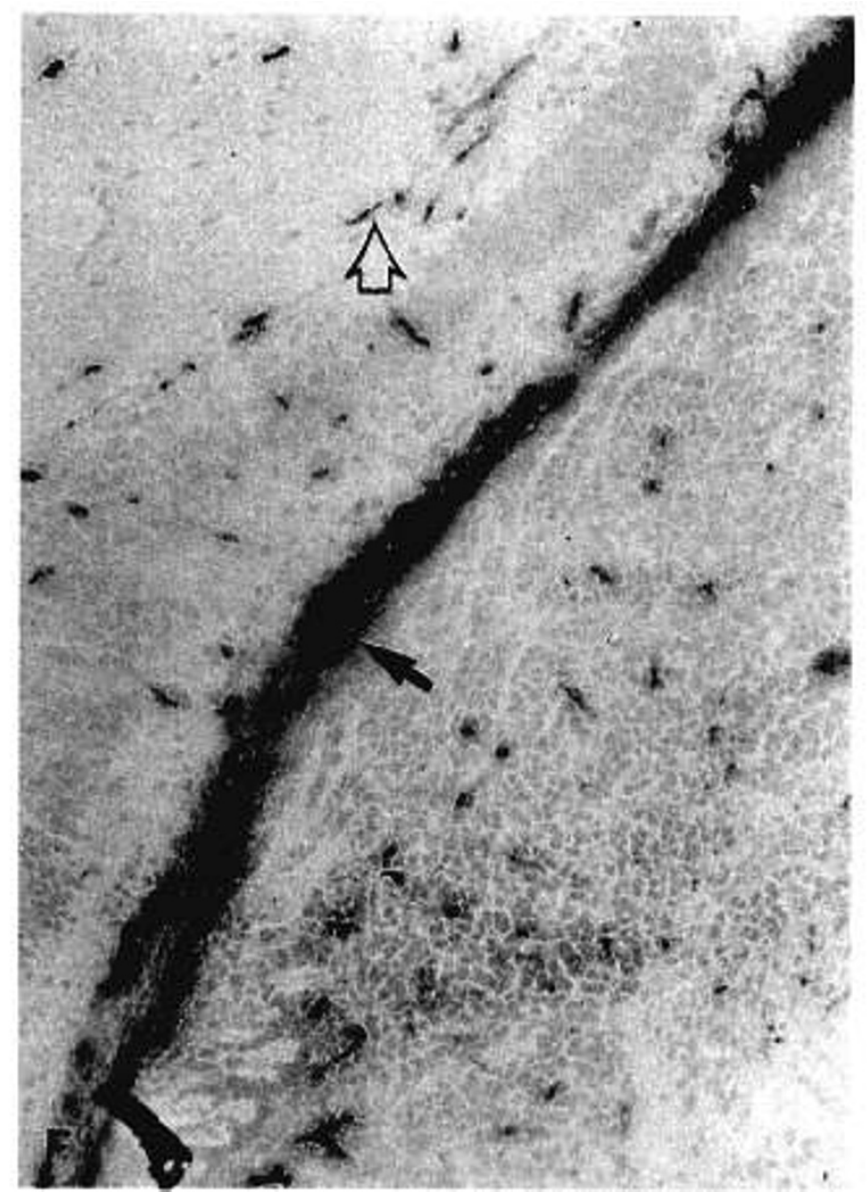

Fig. $1 F$

\section{DISCUSSION}

Recombinant $\beta$-gluc is taken up by many tissues and cell types in the newborn MPS VII mouse. Presumably, rapid clearance of enzyme from plasma is mediated by mannose and Man 6-P receptors. Participation of the Man 6-P receptor in enzyme uptake is suggested by the correlation of the distribution of enzyme with the receptor's previously reported location in fetal and newborn rodents $(5,6,10)$. Sites reached after i.v. injection of $28000 \mathrm{U}$ of $\beta$-gluc, which is 3 to 5 times the amount of enzyme present in a homozygous normal pup, include the brain,

\begin{tabular}{|c|c|c|}
\hline & $\begin{array}{c}\text { MPS VII mouse } \\
1 \mathrm{~h} \text { after enzyme } \\
\text { injection }\end{array}$ & $\begin{array}{c}\text { Normal mouse, } \\
\text { no enzyme }\end{array}$ \\
\hline \multicolumn{3}{|l|}{ Bone } \\
\hline Osteoid & +++ & ++ \\
\hline Perichondrium & $+($ focal $)$ & + \\
\hline Chondrocytes & $++($ focal $)$ & ++ \\
\hline Bone marrow & ++ & ++ \\
\hline \multicolumn{3}{|l|}{ Nervous system } \\
\hline Meninges & ++ & + \\
\hline Choroid plexus & +++ & $+($ focal $)$ \\
\hline Vessels & + & + \\
\hline Neurons (CNS) & - & - \\
\hline Satellite cells, ganglia & ++ & + \\
\hline Ganglion cells & + & $+($ focal $)$ \\
\hline Nerve trunks & + & + \\
\hline \multicolumn{3}{|l|}{ Heart } \\
\hline Endocardium & +++ & - \\
\hline Myocardium & + & - \\
\hline \multicolumn{3}{|l|}{ Other tissues } \\
\hline Liver & +++ & ++ \\
\hline Spleen & $++t$ & ++ \\
\hline \multicolumn{3}{|l|}{ Stomach } \\
\hline $\begin{array}{l}\text { Columnar epithe- } \\
\text { lium }\end{array}$ & - & ++ \\
\hline Lamina propria & ++ & + \\
\hline \multicolumn{3}{|l|}{ Small intestine } \\
\hline Villus epithelium & +++ & +++ \\
\hline Crypt epithelium & - & - \\
\hline Lamina propria & +++ & - \\
\hline Muscularis & - & - \\
\hline Kidney & +++ & + \\
\hline Adrenal & ++ & + \\
\hline Brown fat & ++ & + \\
\hline \multicolumn{3}{|l|}{ Skin } \\
\hline Epidermis & - & - \\
\hline Dermis & + & + \\
\hline \multicolumn{3}{|l|}{ Lung } \\
\hline Smooth muscle & ++ & - \\
\hline $\begin{array}{l}\text { Columnar epithe- } \\
\text { lium }\end{array}$ & - & + \\
\hline Great vessels & ++ & - \\
\hline \multicolumn{3}{|l|}{ Skeletal muscle } \\
\hline Fibers & - & - \\
\hline Vessels & ++ & + \\
\hline Eye sclera & +++ & - \\
\hline
\end{tabular}

$*+++$, Intense staining; ++ , moderate staining; + , weak staining; - , no enzyme detected histochemically.

Fig. 1. $A-C$, Sagittal sections of whole-mounted pups, stained for $\beta$-gluc activity. Positive tissues stain bright red. $A$, An MPS VII control pup contains no tissue enzyme activity. $B$, An MPS VII pup $1 \mathrm{~h}$ after $\beta$-gluc injection shows intense staining in many sites including the liver, bone, and heart. There is also enzyme in the CNS, particularly in the choroid plexus stria vascularis, meninges, and vessels. $C$, A homozygous normal control pup has less intense staining for $\beta$-gluc except in the intestine. $D$ - $F$, Tissues from an MPS VII pup $1 \mathrm{~h}$ after $\beta$-gluc injection, stained for $\beta$-gluc activity. $D$, The endocardium (arrow) of the atrium $(A)$ and ventricle $(V)$ is decorated by intense staining for $\beta$-gluc. $E$, Bones in all sites examined have intense $\beta$-gluc activity in the osteoid, osteoblasts, and osteocytes. The marrow also contains enzyme activity. $F$, The brain has $\beta$-gluc activity in the meninges (black arrow) and vessels (open arrow) (naphthol ASBI- $\beta$-glucuronide, $A-C 4.7 \times, D 51 \times, E 128 \times$, and $F 128 \times$ ). 
Table 2. Percent of normal $\beta$-gluc activity in MPS VII pups after enzyme injection and $\beta$-gluc half-life during 1 st wk of life

\begin{tabular}{lrrr} 
& \multicolumn{2}{c}{ Percent normal } & Half-life in \\
\cline { 2 - 3 } Organ & $1 \mathrm{~h}$ & $1 \mathrm{wk}$ & \\
\cline { 2 - 3 } heart & 2300 & 14.3 & $34(0.979)$ \\
Liver & 1300 & 39.8 & $50(0.994)$ \\
Kidney & 209 & 13.2 & $72(0.939)$ \\
Lung & 137 & 2.7 & $36(0.982)$ \\
Spleen & 99 & 7.8 & $84(0.936)$ \\
Brain & 31 & 1.4 & $108(0.924)$ \\
\hline
\end{tabular}

bone, heart, and fixed tissue macrophage system. Thus, $\beta$-gluc is targeted to sites that exhibit clinically important lysosomal storage in MPS VII

The relative level of $\beta$-gluc activity in the CNS achieved by a single injection in the newborn MPS VII mouse is substantially higher than that produced by neonatal BMT (11). Thus, the CNS may respond better to early enzyme therapy than to BMT performed immediately after birth. Achieving $\beta$-gluc levels of $31 \%$ normal in the CNS is significant because enzyme levels as low as $2 \%$ and $6 \%$ have been shown to markedly reduce morphologic evidence of lysosomal storage in the liver and spleen, respectively (7). Although enzyme replacement may prove to be beneficial as a sole form of therapy in MPS (as is clearly the case in Gaucher disease), replacement therapy might also be used as a bridge to BMT. With this approach, exposure of newborn MPS VII mice to radiation, which causes growth retardation and focal dysplasia of the CNS (11), would be avoided. Therapeutic levels of infused enzyme could prevent lysosomal glycosaminoglycan accumulation until mice are old enough to safely undergo BMT.

\section{REFERENCES}

1. Birkenmeier EH, Davisson MT, Beamer WG, Ganschow RE, Vogler CA, Gwynn B, Lyford KA, Maltais LM, Wawrzyniak CJ 1989 Murine mucopolysaccharidosis type VII: characterization of a mouse with $\beta$-glucuronidase deficiency. J Clin Invest 83:1258-1266

2. Vogler C, Birkenmeier EH, Sly WS, Levy B, Pegors C, Kyle JW, Beamer WG 1990 A murine model of mucopolysaccharidosis VII: gross and microscopic findings in $\beta$-glucuronidase-deficient mice. Am J Pathol 136:207-217

3. Barton NW, Furbish FS, Murray GJ, Garfield M, Brady RO 1990 Therapeutic response to intravenous infusions of glucocerebrosidase in a patient with Gaucher disease. Proc Natl Acad Sci USA 87:1913-1916

4. Grubb JH, Kyle JW, Cody LB, Sly WS 1993 Large scale purification of phosphorylated recombinant human $\beta$-glucuronidase from overexpressing mouse $L$ cells. FASEB J 7:A1255(abstr)

5. Senior PV, Byrne S, Brammar WJ, Beck F 1990 Expression of the IGF-II/ mannose-6-phosphate receptor mRNA and protein in the developing rat Development 109:67-73

6. Lee SJ, Nathans D 1988 Proliferin secreted by cultured cells binds to mannose 6-phosphate receptors. J Biol Chem 263:3521-3527

7. Wolfe JH, Sands MS, Barker JE, Gwynn B, Rowe LB, Vogler CA, Birkenmeier EH 1992 Reversal of pathology in murine mucopolysaccharidosis type VI by somatic cell gene transfer. Nature 360:749-753

8. Glaser JH, Sly WS $1973 \beta$-Glucuronidase deficiency mucopolysaccharidosis: methods for enzymatic diagnosis. J Lab Clin Med 82:969-977

9. Bradford MM $1976 \mathrm{~A}$ rapid and sensitive method for the quantitation of microgram quantities of protein utilizing the principles of protein-dye binding. Anal Biochem 72:248-254

10. Matzner U, Von Figura K, Pohlmann R 1992 Expression of the two mannose 6-phosphate receptors is spatially and temporally different during mouse eprogenesis. Development 114:965-972

11. Sands MS, Barker JE, Vogler C, Levy B, Gwynn B, Galvin N, Sly WS Birkenmeier E 1993 Treatment of murine mucopolysaccharidosis type VI by syngeneic bone marrow transplantation in neonates. Lab Invest 68 : 676-686 